\title{
PENDIDIKAN AKHLAK DALAM KELUARGA (Tinjauan Normatif dalam Islam)
}

\author{
Oleh: \\ Ahmad Rifa'i \\ Dosen Sekolah Tinggi Ilmu Al-Qur'an Amuntai \\ Kalimantan Selatan, Indonesia
}

\begin{abstract}
Abstrak
Pendidikan akhlak dalam keluarga merupakan pendidikan utama yang mana disini orangtua sebagai pemeran utamanya. Di dalam sebuah keluarga, orang tua adalah sebagai tokoh idola bagi anak anaknya, dimana setiap gerak-gerik maupun tingkah laku orang tua selalu mendapat perhatian serius dari anak, bahkan anak-anak lebih cenderung meniru tingkah laku orang tuanya. Kecenderungan manusia untuk meniru, lewat peniruan, menyebabkan ketauladanan menjadi sangat penting artinya dalam proses belajar mengajar atau pendidikan keluarga sikap atau perilaku orang tualah yang akan dicontoh dan ditiru oleh anaknya. Jenis penelitian dalam jurnal ini adalah penelitian kepustakaan (Library Research) yaitu sumber data penelitian diperoleh dari perpustakaan. sumber data terdiri atas sumber data primer dan sumber data sekunder. Untuk menganalisis data peneliti menggunakan teknik analisis isi (Content Analisis). Analisi isi adalah teknik penelitian untuk inferensiinferensi yang dapat ditiru dan data tersebut diperoleh dari sumber yang benar. Hasil analisis : Pendidikan keluarga mengajarkan anak akan nilai moral, adab dalam bergaul dengan sesama makhluk Allah, bertetangga, bermasyarakat ataupun bernegara. Ada beberapa metode pendidikan ketika anak dalam kandungan : metode kasih sayang, metode beribadah, metode membaca Alquran, metode pengajian di majelis ta'lim, metode penghargaan dengan ucapan, metode pemberian hadiah, metode bercerita, metode diskusi, metode tadzkirah, metode mengikut sertakan dengan ucapan, metode do'a, dan metode lagu. Sedangkan pendidikan pasca melahirkan dimulai dari upacara-upacara yang disunatkan agama disaat
\end{abstract}


menerima kelahiran bayi berupa azan, aqiqah, tahnik, tasmiyah, tahliyah/cukur sampai kepada dikhitan, semuanya merujuk kepada pendidikan yang harus diberikan kepada anak di awal pertumbuhannya. Pendidikan ini terus berjalan hingga saatnya anak dicarikan pendamping hidupnya/dinikahkan. Inilah kewajiban orangtua dalam mendidik anak, terutama mendidik akhlak dalam keluarga.

Kata Kunci: Pendidikan, akhlak, keluarga

\section{A. Pendahuluan}

Berkenaan dengan lembaga keluarga telah dikenal semenjak Adam memperisteri Hawa dan melahirkan anak keturunannya. Dari keturunan anak cucu Adam inilah timbul masyarakat dan umat manusia. Dalam suatu masyarakat, yang terdiri dari keluarga-keluarga. Pendidikan terus berlangsung sebagai suatu usaha generasi tua untuk mengembangkan potensi generasi mudanya.

Pendidikan mencakup segala usaha dan perbuatan dari generasi tua dalam usaha mengalihkan pengalamannya, pengetahuan kecakapan dan keterampilannya kepada generasi muda untuk memungkinkan melakukan fungsi hidupnya dalam pergaulan dengan sebaik-baiknya. ${ }^{1}$ Dilihat dari proses kronologis keberadan manusia, pendidikan keluarga adalah fase awal dan basis bagi pendidikan seseorang. Ia juga merupakan pendidikan alamiah yang melekat pada setiap rumah tangga. Pendidikan fase awal dan basis ini sangat berpengaruh dan menentukan pendidikan lanjutan, misalnya pendidikan disekolah.

Keluarga adalah salah satu pusat pendidikan, kelembagaan tempat berlangsungnya pendidikan. Malahan keluarga sebagai pusat pendidikan yang alamiah dibandingkan dengan pusat pendidikan lainnya dan diperkirakan pendidikan di keluarga berlangsung dengan penuh kewajaran ${ }^{2}$

h. 8

${ }^{1}$ H.B. Hamdani Ali, Filsafat Pendidikan, (Yogyakarta : Kota Kembang, 1987),

${ }^{2}$ Imam Barnadib, Pemikiran Tentang Pemikiran Baru (Yogyakarta : Andi Offset. 1983), h. 129 
Keluarga merupakan lembaga pendidikan tertua, bersifat informal, yang pertama dan utama dialami oleh anak serta lembaga pendidikan yang bersifat kodrati. Orang tua bertanggung jawab memelihara, merawat, melindungi dan mendidik anak agar tumbuh dan berkembang dengan baik. ${ }^{3}$ Tugas utama dari keluarga bagi pendidikan anak ialah sebagai peletak dasar bagi pendidikan akhlak dan pandangan hidup keagamaan. Sifat dan tabiat anak sebagian besar diambil dari orang tuanya dan dari anggota keluarga yang lain. ${ }^{4}$ Keluarga adalah lingkungan pertama bagi pembentukan ketauhidan anak. ${ }^{5}$

Di dalam sebuah keluarga, orang tua adalah sebagai tokoh idola bagi anak anaknya, dimana setiap gerak-gerik maupun tingkah laku orang tua selalu mendapat perhatian serius dari anak, bahkan anak-anak lebih cenderung meniru tingkah laku orang tuanya. Kecenderungan manusia untuk meniru, lewat peniruan, menyebabkan ketauladanan menjadi sangat penting artinya dalam proses belajar mengajar atau pendidikan keluarga sikap atau perilaku orang tualah yang akan dicontoh dan ditiru oleh anaknya. Berdasarkan uraian di atas, penting untuk dipelajari bagaimana pendidikan akhlak dalam keluarga.

\section{B. Metode Penelelitian}

Metode adalah cara yang digunakan untuk mencari kebenaran dalam melakukan suatu penelitian. Sugiyono menjelaskan dalam bukunya bahwa metode penelitian adalah cara ilmiah untuk mendapatkan data yang valid dengan tujuan dapat menemukan, mengembangkan dan membuktikan teori ilmu pengetahuan untuk memahami, memecahkan dan mengantisipasi masalah dalam bidang pendidikan. ${ }^{6}$

${ }^{3}$ Hasbullah, Dasar-Dasar Ilmu Pendidikan, (Jakarta : Raja Grafindo Prrsada, 2006), h. 38

${ }^{4}$ Amir Daien Indrakusuma, Pengantar Ilmu Pemdidikan, (Surabaya: Usaha Nasional, 1973), h.

109

${ }^{5}$ Agus Setiawan, Konsep Pendidikan Tauhid dalam Keluarga Perspektif Pendidikan Islam, EDUCASIA, Vol. 2 No. 1, 2017.

${ }^{6}$ Sugiyono, Metode Penelitian Pendidikan (Bandung: Alfabeta, 2010), Cet, 10, h. 6 . 


\section{Jenis penelitian}

Jenis penelitian adalah penelitian kepustakaan (Library Research) yaitu sumber data penelitian diperoleh dari perpustakaan. Perpustakaan merupakan pusat tempat menyediakan berbagai buku agama maupun umum, kitab-kitab, jurnal, majalah dan dokumen. Dari berbagai sumber bacaan tersebut ditemukan konsep-kosep, teori, pemikiran untuk dikembangkan dan diuji kebenarannya sehingga perlu dilakukan penelitian.

2. Sumber data penelitian

Pada penelitian ini sumber data terdiri atas sumber data primer dan sumber data sekunder. Data primer adalah data yang menjadi bahan utama dalam melakukan penelitian yaitu buku-buku yang mengangkat dan membahas tentang pendidikan keluarga Islam. Sedangkan data sekunder adalah data yang memiliki kaitan dengan data primer yaitu Alquran, haditshadits, buku-buku pendidikan anak, filsafat pendidikan, kamus, dll.

3. Teknik pengumpulan data

Untuk memperoleh data-data yang diperlukan dalam penyusunan ini, penulis menggunakan penelitian kepustakaan (library research) dengan langkah-langkah:

a. Membaca buku-buku sumber, baik primer maupun sekunder.

b. Mempelajari dan mengkaji serta memahami kajian yang ada dalam buku-buku sumber.

c. Menganalisis untuk diteruskan identifikasi dan mengelompokkan serta mengklarifikasi sesuai dengan sifatnya masing-masing dalam bentuk bab per bab.

4. Metode analisis data

Setelah semua data diperoleh dan dikumpulkan, langkah yang harus dilakukan selanjutnya adalah menganalisis data sebagai cara untuk menghasilkan penelitian dari masalah yang diteliti. Peneliti menggunakan teknik analisis isi (Content Analisis). Analisi isi adalah teknik penelitian 
untuk inferensi-inferensi yang dapat ditiru dan data tersebut diperoleh dari sumber yang benar. ${ }^{7}$

\section{Tinjauan Teoritis}

\section{Pengertian Pendidikan Keluarga}

Dalam bahasa Arab istilah pendidikan dikenal dengan kata tarbiyah dengan kata kerjanya rabba-yurabbi-tarbiyatan yang berarti mengasuh, mendidik, dan memelihara. ${ }^{8}$ Kata kerja rabba (mendidik) sudah digunakan pada zaman Nabi Muhammad SAW seperti terlihat dalam dalam ayat Al-Qur'an surah al-Isra ayat 24 :

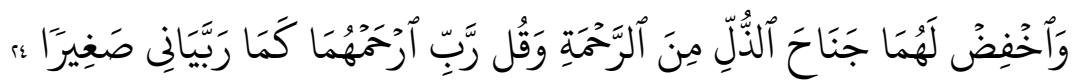

Artinya : Dan rendahkanlah dirimu terhadap mereka berdua dengan penuh kesayangan dan ucapkanlah: "Wahai Tuhanku, kasihilah mereka keduanya, sebagaimana mereka berdua telah mendidik aku waktu kecil".

Ditinjau dari aspek kebahasaan, dalam bahasa Inggris, kata keluarga adalah "family" yang berasal dari kata familier yang berarti dikenal baik atau terkenal. Lebih lanjut, Mahyuddin memberikan pengertian bahwa keluarga dalam arti sempit disebut pure family system (sistem keluarga yang asli) adalah unit atau kelompok yang kecil dalam masyarakat yang terdiri dari ayah, ibu dan anak. Keluarga dalam arti yang luas (extented family system) adalah ayah, ibu, anak-anak dan sebagainya yang kebutuhan hidupnya semua tergantung pada keluarga. ${ }^{9}$ Dalam Kamus Besar Bahasa Indonesia keluarga adalah ibu dan bapak beserta anak-anaknya atau satuan kekerabatan yang sangat mendasar di masyarakat. ${ }^{10}$

\footnotetext{
${ }^{7}$ Khatibah, Penelitian Kepustakaan, Jurnal iqra, Vol. 5, No. 1, h. 10.

${ }^{8}$ A.Warson Munir, Kamus Al-Munawir, (Yogyakarta: Unit Pengadaan Bukubuku Ilmiah Keagamaan, Cet. I, 1984), h. 504

${ }^{9}$ Mahmud dkk., Pendidikan Agama Islam Dalam Keluarga: Sebuah Panduang Lengkap Bagi Guru, Orang Tua, dan Calon, (Jakarta: Akademia, 2013), h. 127-128.

10 Pusat Bahasa, Tim Penyusun Kamus, Kamus Besar Bahasa Indonesia, (Jakarta: Balai Pustaka, 2005), h. 536.
} 
Keluarga dalam hubungan darah merupakan suatu kesatuan sosial yang diikat oleh hubungan darah antar satu dengan lainnya. Sedangkan dalam dimensi hubungan sosial, keluarga merupakan suatu kesatuan sosial yang diikat oleh adanya saling berhubungan atau interaksi dan saling mempengaruhi antara satu dengan lainnya, walaupun di antara mereka tidak terdapat hubungan darah. $^{11}$

Pendidikan dalam keluarga adalah pendidikan yang berlangsung dalam keluarga, yang dilaksanakan oleh orang tua sebagai tugas dan tanggung jawabnya dalam mendidik anak dalam keluarga. ${ }^{12}$ Dalam Undang-undang Sistem Pendidikan Nasional pasal 1 ayat (13) disebutkan bahwa Pendidikan Informal adalah jalur pendidikan keluarga dan lingkungan.11 Pendidikan Informal berasal dari pengalaman sehari-hari dan terjadi dari lahir sampai akhir hayat sehingga bersifat tidak teratur dan bersifat mandiri. Pendidik dalam pendidikan informal ada di bawah tanggung jawab orang tua. ${ }^{13}$

Pendidikan keluarga memberikan pengetahuan dan keterampilan dasar, agama, kepercayaan, nilai moral, norma sosial dan pandangan hidup yang diperlukan anak untuk dapat berperan dalam keluarga dan masyarakat. ${ }^{14}$ Sementara itu, menurut rumusan Badan Kordinasi Keluarga Berencana Nasional, yang dimaksud keluarga yang berkualitas adalah keluarga yang memenuhi cir-ciri: keluarga yang sejahtera,sehat, maju, mandiri, memiliki jumlah anak ideal, berwawasan kedepan, bertanggung jawab, harmonis, dan bertakwa kepada Tuhan Yang Maha Esa. ${ }^{15}$

${ }^{11}$ Shochib, Moh., Pola Asuh Orang Tua: Dalam Membantu Mengembangkan Disiplin Diri Sebagai Pribadi Yang Berkarakter, (Jakarta: Rineka Cipta: 2010), Cet. II, h. 17.

${ }^{12}$ Djamarah, Pola Asuh..., h. 2.

${ }^{13}$ Undang-undang Nomor 20 Tahun 2003, Sistem Pendidikan Nasional, Pasal 1 ayat (13)

${ }^{14}$ Ihsan, Fuad, Dasar-dasar Kependidikan: Komponen MKDK, (Jakarta: Rineka Cipta, 2010), Cest. VI, h. 17-19.

${ }^{15}$ Ismail, Asep Usman, Al-Qur'an dan Kesejahteraan Sosial: Sebuah Rintisan Membangun Paradigma Sosial Islam Yang Berkeadilan dan Berkesejahteraan, (Tangerang: Lentera Hati, 2012), h. 151 
Oleh karena itu rumah keluarga muslim menjadi sekolah/madrasah pertama sebagai benteng utama tempat anak-anak dibesarkan melalui pendidikan Islam. Yang dimaksud keluarga muslim adalah keluarga yang mendasarkan aktivitas pada pembentukan keluarga yang berpondasikan Alquran dan Hadis sebagai rujukan utama. Dan kita dapat mengatakan bahwa tujuan terpenting dari pembentukan keluarga melalui hal-hal berikut :

a. Mendirikan syariat Allah dalam segala permasalahan rumah tangga. Artinya, tujuan berkeluarga adalah mendirikan rumah tangga muslim yang mendasarkan kehidupannya pada perwujudan penghambaan kepada Allah.

b. Mewujudkan ketenteraman dan ketenangan psikologis. Allah berfirman dalam al-A'raf ayat 189 :

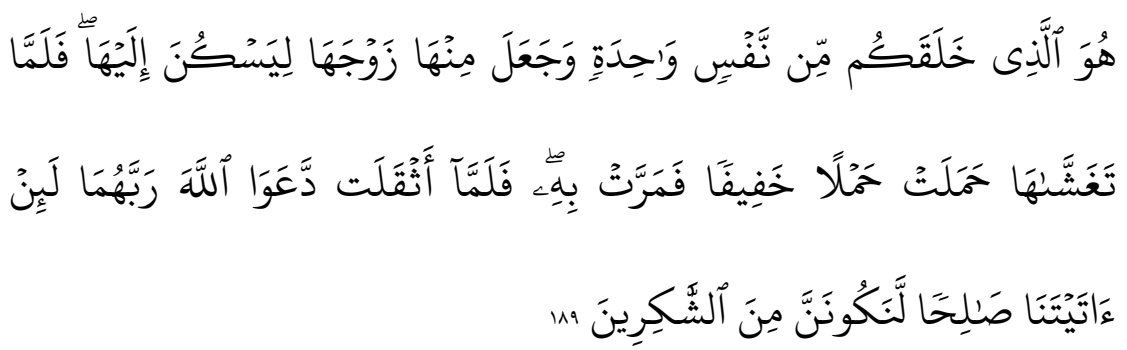

Artinya : Dialah yang menciptakan kamu dari diri yang satu dan dari padanya Dia menciptakan isterinya, agar Dia merasa senang kepadanya. Maka setelah dicampurinya, isterinya itu mengandung kandungan yang ringan, dan teruslah Dia merasa ringan (Beberapa waktu). kemudian tatkala Dia merasa berat, keduanya (suami-isteri) bermohon kepada Allah, Tuhannya seraya berkata: "Sesungguhnya jika Engkau memberi Kami anak yang saleh, tentulah Kami terraasuk orang-orang yang bersyukur".

Jika suami-isteri bersatu diatas landasan kasih-sayang dan ketenteraman psikologis yang interaktif, anak-anak akan tumbuh dalam suasana bahagia, percaya diri, tenteram, kasih-sayang, serta jauh dari 
kekacauan, dan jauh dari penyakit batin yang melemahkan kepribadian anak.

a. Mewujudkan sunnah Rasulullah Saw, dengan melahirkan anakanak saleh.

b. Memenuhi cinta dan kasih kepada anak-anak. Keluarga, terutama orangtua bertanggung jawab untuk memberikan kasih sayang kepada anak-anaknya, karena kasih sayang merupakan landasan terpenting dalam pertumbuhan dan perkembangan psikologis dan sosial anak. ${ }^{16}$

\section{Pendidikan Akhlak dalam Keluarga}

\section{a. Pendidikan anak dalam kandungan}

Anak didalam kandungan adalah anak yang masih berada didalam perut ibunya atau anak yang belum lahir. Istilah lain untuk anak dalam kandungan adalah anak pranatal. Dengan demikian, yang dimaksud dengan pendidikan anak dalam kandungan adalah pendidikan anak yang belum lahir atau mendidik anak yang masih berada didalam perut ibunya.

Jika dikaitkan dengan pengertian pendidikan yang dirumuskan diatas maka pendidikan anak dalam kandungan adalah usaha sadar orangtua (suami-isteri) untuk mendidik anak yang masih didalam perut ibunya. Usaha sadar ini ditunjukan khusus kepada kedua orangtua nya, karena anak dalam kandungan memang belum mungkin dididik, apalagi diajar, kecuali oleh orangtua nya sendiri. ${ }^{17}$

Adapun metode mendidik anak dalam kandungan adalah ${ }^{18}$ :

1) Metode kasih sayang

Kasih sayang, meskipun tidak dapat dikatagorikan kedalam metode secara tepat, tetapi tepat untuk anak dalam kandungan kerena ia

16 Abdurrahman An-Nahlawi, Pendidikan Islam di Rumah, Sekolah ,dan Masyarakat, (Jakarta: Gema Insani Press: 2010), Cet. II, h. 139-141

${ }^{17}$ Baihaki. A.K, Mendidik Anak Dalam Kandungan Menurut Ajaran Pedagogis Islam, ( Jakarta : Darul Ulum Press. 2000), h. 11

${ }^{18}$ Ibid., h. 153-166 
merupakan rangsangan yang dibuat untuk menjadi kunci pembuka bagi melangkah kepada metode selanjutnya.

2) Metode beribadah

Ibu hamil yang beribadah, dengan sendirinya mengikutsertakan anak yang dikandungnya beribadah. Contoh yang paling ringan dalam hal ini adalah ibadah shalat. Seorang ibu hamil yang mendirikan shalat tidak mungkin mengeluarkan anaknya lalu menyerahkannya untuk sementara kepada orang lain. Kemudian setelah shalat ia meminta lagi anaknya itu dimasukkan kedalam perut. Yang terjadi dalam realita adalah bahwa anak yang di dalam kandungan ikut bersama ibunya mendirikan shalat, atau perbuatan ibadah lainnya.

3) Metode membaca Alquran

Sama halnya dengan ibadah di atas, membaca Alquran merupakan metode mendidik anak dalam kandungan yang sangat relevan. Ketika seorang ibu hamil membaca Alquran, maka dengan sendirinya telah memberi rangsangan edukatif yang amat positif dan sekaligus telah membina lingkungan yang baik lagi Islami bagi anak yang dikandungnya.

4) Metode mengikuti pengajian di Majelis-majelis ta'lim

Sama halnya dengan mengaji Alquran, ibu hamil yang mengikuti pengajian di majelis ta'lim berarti merangsang bayi yang dikadungnya untuk mengikuti pengajian dan sejalan dengan itu, ia telah membina lingkungan yang baik lagi Islami bagi dirinya dan bayinya.

5) Metode penghargaan dengan ucapan

Metode ini dilakukan melalui ibu dari bayi yang sedang dikandung. Misalnya, jika ibu merasa bayinya bergerak lalu berkata ; "Alhamdulillah bayiku sehat dan aktif", atau sang ayah juga menyahut :"Alhamdulillah, anak kita sehat dan aktif. Mudah- 
mudahan ia dijadikan Allah anak yang shaleh lagi pintar dan cerdas". Hal ini dengan sendirinya membuat mereka merasa gembira dan bersenang hati, juga meragsang bayi mereka ikut gembira dan bersenang hati.

6) Metode pemberian hadiah

Dalam hal ini sebagai contoh, ketika seorang suami membelikan susu ibu hamil buat diminum ibu dari bayi yang masih dalam kandungan, lalu berkata ;"ini susu enak yang abi hadiahkan untuk bayi kita, supaya ia sehat dan cerdas". Isteri yang mendengar ucapan itu, tentulah sangat bahagia dan gembira dan ikut gembira bersamanya bayi yang sedang dikandung. Atau boleh hadiah-hadiah yang lain seperti membelikan isteri sehelai kain daster yang bagus, dll.

7) Metode bercerita

Metode bercerita dapat digunakan untuk mendidik anak dalam kandungan. Caranya adalah dengan menceritakan sesuatu yang baik kepadanya melalui isteri yang sedang mengandungnya. Cerita para nabi, para sahabat, pejuang-pejuang Islam lainnya. Para ulama besar, para wali, para sufi yang terkenal, dan sebagainya dapat dijadikan bahan cerita untuk anak dalam kandungan.

8) Metode diskusi

Diskusi yang dimaksud adalah diskusi antara suami isteri, atau dengan orang lain di rumah. Topik diskusi carilah yang ringanringan saja dan menyenangkan, seperti doa'a-do'a harian dan lainlain.

9) Metode Tadzkirah

Tadzkirah artinya mengingatkan. Jadi, metode ini mengingatkan orang-orang yang lalai atau melalaikan pengamalan suatu ibadah 
yang menghubungkan kita kepada sang Khaliq atau amalan, seperti : Shalat, puasa, zakat, dll. Dan bisa -lembut ${ }^{19}$ padanya.

10) Metode mengikut sertakan dengan ucapan

Yang dimaksud dengan mengikutsertakan dengan ucapan adalah mengajak anak dalam kandungan dengan kata-kata bersama melakukan perbuatan-perbuatan baik, atau amal-amal shaleh dan ibadah-ibadah yang akan dikerjakan ibu yang sedang mengandung. Contohnya :

a) Jika akan berwudu, ibu yang mengandungnya berkata :'Nak, ayo sama-sama kita mengambil air wudu' untuk shalat".

b) Jika akan shalat, ibu yang mengandungnya berkata :"Nak, ayo sama-sama kita kita shalat agar disayang Allah”.

c) Jika akan berzikir, ibu yang mengandungnya berkata :"Nak, ayo sama-sama kita berzikir untuk mengingat Allah".

d) Jika akan bersedekah, ibu yang mengandungnya berkata :'Nak, ayo sama-sama kita bersedekah membantu sesama."

e) Jika ayahnya pulang dari pekerjaan, ibu yang mengandungnya berkata :’Nak, ayo sama-sama kita menyambut abi di pintu depan".

11) Metode do'a

Banyak do'a-do'a dalam Alquran yang baim dilantunkan oleh ibu yang sedang mengandung, diantaranya pada surah As-Shaffat ayat 100 :

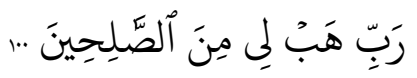

19 Suami atau isteri yang tidak sopan dan lemah lembut akan membuat hubungan mereka akan menjadi renggang dan akan saling menjauh. Kerenggangan itu bermuara pada ketidakrukunan yang akibatnya berpengaruh negatif pada anak prenatal (Ahmad Tafsir, Pendidikan Agama Dalam Keluarga, Bandung : PT. Remaja Rosdakarya. 2000, cetakan ke 3 h. 48 
Artinya : Ya Tuhanku, anugrahkanlah kepadaku (seorang anak) yang Termasuk orang-orang yang saleh.

Dan pada surah Ibrahim ayat 40 :

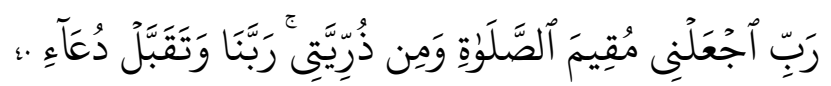

Artinya : Ya Tuhanku, Jadikanlah aku dan anak cucuku orangorang yang tetap mendirikan shalat, Ya Tuhan Kami, perkenankanlah doaku.

12) Metode lagu

Metode lagu merupakan metode yang baik bagi upaya mendidik anak dalam kandungan, lebih-lebih jika yang dilakukan itu kalimatkalimat tahyyibah, atau lagu-lagu bernapaskan Islami.

Dari semua metode di atas, dapat disimpulkan bahwa ketika dalam kandungan potensi pendengaran anak lebih peka dari panca indera lainnya. Hal ini sudah Allah tegaskan pada surah Isro' ayat 36 :



Artinya: Sesungguhnya pendengaran, penglihatan dan hati, semuanya itu akan diminta pertanggungan jawabnya.

Dari urutan kalimat yang disampaikan dalam ayat ini "pendengaran" masuk dalam urutan pertama, baru dilanjutkan penglihatan, dan hati. Ini menegaskan kepada kita bahwa bayi ketika didalam kandungan potensi pendengarannya lebih peka dari indera yang lainnya.

\section{b. Pendidikan pasca melahirkan}

Jika diperhatikan upacara-upacara yang disunatkan agama disaat menerima kelahiran bayi berupa azan, aqiqah, tahnik, tasmiyah, 
tahliyah/cukur sampai kepada dikhitan ${ }^{20}$, semuanya merujuk kepada pendidikan yang harus diberikan kepada anak di awal pertumbuhannya.

Ibn al-Qayyim aj-Jauzi memberi komentar mengenai rahasia di azankan di telinga anak yaitu agar yang didengar oleh bayi sewaktu lahir kedunia adalah ungkapan yang mengandung makna kebesaran dan keanguugan Allah, yang diiringi oleh kalimat syahadat sebagai kalimat pertama ketika masuk Islam, juga merupakan pelajaran tentang syiar Islam dan kalimat tauhid. ${ }^{21}$

Aqiqah bisa diberi makna sebagai pengajaran untuk bersyukur dan bermurah hati. Cerita mengenai anak yang telah diaqiqahi dengan menyembelih kambing yang dibagikan kepada jiran tetangga akan didengar oleh anak sejak dia kecil dan akan membekas dalam jiwanya. Demikian pula maksud dan harapan dari pemberian nama yang indah sebagai penghantar yang positif di awal pertumbuhannya. Tahnikah dengan memasukkan makanan korma yang halal oleh seorang yang soleh pembentukan situasi yang positif. Begitupula tahliyah atau mencukur rambutnya sebagai usaha pembersihan dari kotoran di kepala anak merupakan titik awal dari mencitai kebersihan.

${ }^{20}$ Nilai-nilai pendidikan yang terkandung dalam khitan : 1. Merupakan syiar Islam serta membedakan antara muslim dan non muslim. 2. Merupakan pernyataan ubudiyah kepada Allah, serta kepatuhan kepada-Nya. 3. Dengan terkelupasnya kulit ulu zakar berarti seseorang akan selamat dari peluh berminyak dan sisa kencing yang mengadung lemak dan kotor. Sisa-sisa tersebut tentu bisa mengakibatkan gangguan kencing dan pembusukan. 4. Khitan dapat mengurangi kemungkinan berjangkitnya kanker kelamin. Kenyataan ini menunjukkan bahwa kanker banyak berjangkit pada orang-orang yang kulufnya sempit, dan jarang terdapat pada bangsa-bangsa yang berpegang pada wajibnya khitan 5. Dapat menghindarkan anak dari penyakit ngompol. 6. Bagi perempuan khitan dapat mengurangi syahwatnya, yakni mengurangi gejolak syahwat yang berlebihan terutama bagi wanita yang hyper sex. 7. Khitan dapat menimbulkan kebersihan dan keindahan bentuk zakar. (Ramayulis dkk, Pendidikan Islam Dalam Rumah Tangga. Jakarta : Kalam Mulia. 1990. Cetakan ke 2 h. 131-132)

21 Muhammad 'Ali Quthb, Sang Anak dalam Naungan Pendidikan Islam (Auladuna fi Dau'I al Tarbiyah al Islamiah), Bahrun Abu Bakar Ihsan (Bandung : Diponegoro, 1988), h. 38 
Berkenaan dengan awal pertumbuhan ini Islam sangat memperhatikan. Sebab pase ini menentukan bagi perkembangan anak selanjutnya. Dan keluarga sangat berpengaruh dalam pertumbuhan awal anak.

Menurut Atiah al-Abrasyi pendidikan keluarga itu sangat besar pengaruhnya, antara lain :

1) Dalam bahasa dan logat bicara, yang mana anak bicara dengan bahasa ibunya. Maka jika pembicaraan ibu itu baik, akan baik pula pembicaraan ibunya.

2) Dalam tingkah laku, adab dan pergaulan anak. Adab yang luhur akan timbul pada keluarga yang luhur. Suasana yang tercipta dalam pembentukan akhlaknya. ${ }^{22}$

Dalam kaitannya dengan pembinaan keimanan dan keislaman, Abdullah Ulwani menekankan tanggung jawab orangtua, yaitu meliputi :

1) Memberi petunjuk, mengajari agar beriman dengan Allah dengan jalan merenungkan dan memikirkan ciptaan bumi dan langit secara bertahap dari penginderaan kepada akal, bagian menuju keseluruhan, dari sederhana ke kompleks sehingga memperkokoh keimanan.

2) Menanamkan kedalam jiwanya roh kekhusukan, ketakwaan dan ibadah kepada Allah. Memperdalam takwa melalui latihan shalat pada usia tamyiz dengan tekun, melatih beradap dengan rasa haru dan menangis di saat mendengar alunan suara Alquran.

3) Mendidik untuk dekat kepada Allah disetiap kegiatan dan situasi. Meletih bahwa Allah selalu mengawasi, melihat, mengetahui segala rahasia. Jelasnya orangtua menunjukkan dengan amal, pikiran dan

${ }^{22}$ Muhammad Atiyah al Abrasyi, Ruh at-Tarbiyah wa at-Ta'lim (Qahirah : Daru Ihya'I al-Kutubi al-Arabiah, 'Esa al-Baby al-Halaby wa Syirkah, 1955), h. 88-89 
perasaan, juga melatih melalui pengajaran keikhlasan kepada Allah dalam perkataan , perbuatan dan seluruh aktivitasnya. ${ }^{23}$

Keluarga berkewajiban mengajarkan ilmu fardu 'ain kepada anakanaknya, yaitu menyangkut ibadah dasar seperti hal ihwal shalat, puasa, zakat, haji, dan sebagainya yakni ilmu-ilmu yang berkaitan dengan kewajiban sehari-sehari seseorang muslim.

Allah perintahkan kepada para orangtua untuk mendidik anak-anak dalam hal shalat, sebagaimana yang tertuang dalam hadis Rasulullah :

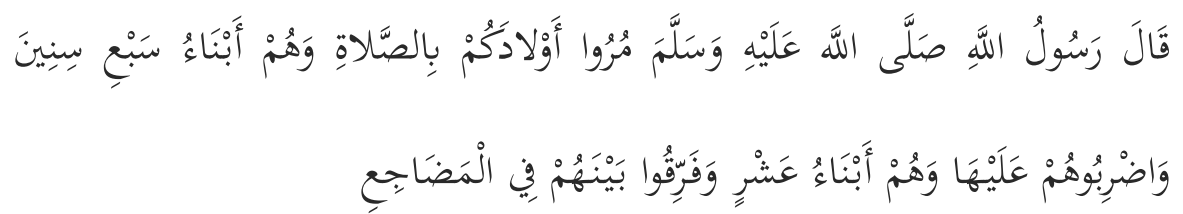

Artinya : Bersabda Rasulullah Saw. Perintahlah anak-anakmu untuk mendirikan shalat jika mereka telah berusia tujuh tahun dan pukullah jika umurnya telah mencapai sepuluh tahun dan pisahlah tempat tidur diantara mereka. $^{24}$

Demikian pula digambarkan oleh Alquran tentang keharusan mendidik anak untuk mendirikan shalat, sebagaimana Lukman mendidik anaknya dengan hikmah. Surah Lukman ayat 17 :

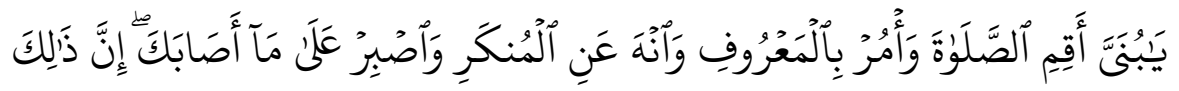

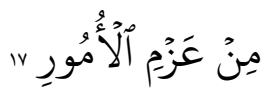

Artinya : Hai anakku, dirikanlah shalat dan suruhlah (manusia) mengerjakan yang baik dan cegahlah (mereka) dari perbuatan yang mungkar dan bersabarlah terhadap apa yang menimpa kamu.

${ }^{23}$ Abdullah Ulwani, Tarbiyah al-Auladi fi al-Islam, Juz 1 (Beirut : Dar asSalam,1981), h. 38

${ }^{24}$ Muhammad Muhyi ad-Din Abd Hamid, Sunan Abi Daud, Juz 1 (Beirut : Dar al-Fikr), h.134 
Ahmad Rifa'i: Pendidikan Akhlak dalam Keluarga (Tinjauan Normatif dalam Islam)

Sesungguhnya yang demikian itu Termasuk hal-hal yang diwajibkan (oleh Allah).

Dalam kaitan dengan ilmu ibadah dasar, pengajaran Alquran seyogyanya diberikan langsung oleh orangtua karena orang tua lebih mengenal sifat anaknya sehingga mudah menanamkan nilai akan mencintai Alquran dan ibadah yang diajarkan kepada anak, sebab menurut Noeng Muhadjir, siapapun yang menjadi pendidik, termasuk orangtua harus memiliki tiga persyaratan : memiliki pengetahuan lebih; mengimplisitkan nilai dalam pengetahuannya itu dan bersedia menularkan pengetahuan beserta nilainya kepada orang lain. ${ }^{25}$

Untuk itu ada tiga hal yang diperintahkan dalam mendidik anakanak kita, seperti hadist yang diriwayatkan oleh At-Tabrani dari Ali bin Abi Thalib RA bahwa Rasululloh SAW bersabda:

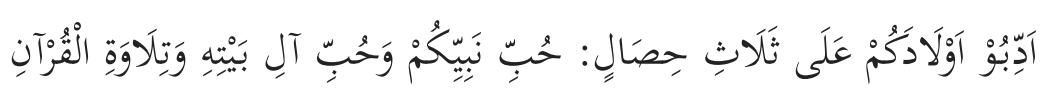

Artinya :"Didiklah anak-anakmu atas tiga hal; mencintai nabimu, mencintai ahli baitnya dan membaca al-Qur'an”.

Mendidik anak-anak ini terus berjalan hingga tiba waktunya menghantarkan anak untuk mampu berdiri sendiri (menikahkannya).

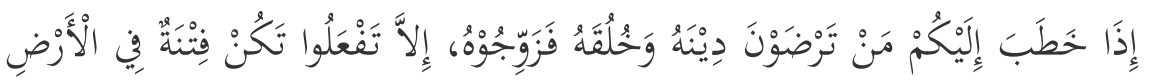

$$
\text { وَفَسَادُ عَرِيْضِّ }
$$

Artinya :"Apabila seseorang yang kalian ridhai agama dan akhlaknya datang kepada kalian untuk meminang wanita kalian, maka hendaknya kalian menikahkan orang tersebut dengan wanita kalian. Bila kalian tidak melakukannya niscaya akan terjadi fitnah di bumi dan kerusakan yang besar."

25 Noeng Muhadjir, Ilmu Pendidikan dan Perubahan Sosial Suatu Teori Pendidikan (Yogyakarta : Rake Sarasin,1987), h. 95 


\section{Analisis Hasil Kajian}

\section{Pendidikan Keluarga}

Pendidikan keluarga adalah pendidikan informal yang dilaksanakan dalam sebuah rumah tangga yang mana orangtua berperan sebagai pendidik utama, dan anak-anak sebagai murid atau anak didik, serta rumah sebagai sekolahnya. Materi pembelajarannya pun menyesuaikan keilmuan kedua orangtuanya, oleh karena itulah orangtua dituntut belajar lebih banyak, untuk bekal persiapan transper ilmu kepada anak-anak. Ilmu-ilmu dasar yang diberikan pada anak seperti mempertajam pengetahuan agamanya, memperkuat keimanan kepada Allah Yang Maha Esa agar tidak terpengaruh dalam arus gelombang ujian diluar sana yang bisa mempenaruhi gaya berfikir anak, sehingga anak melenceng kepada pemahaman keagamaan dan keimanan yang sesat. Pendidikan keluarga juga mengajarkan anak akan nilai moral, adab dalam bergaul dengan sesama makhluk Allah, bertetangga, bermasyarakat ataupun bernegara. Adab yang diajarkanpun dimulai dengan adab standar yang bisa diperaktikan oleh anak, seperti mengetuk pintu disertai salam ketika masuk rumah, bersalaman dengan orangtua ketika berangkat sekolah, menunduk ketika lewat didepan orangtua, berbicara dengan lemah lembut, memanggil panggilan "kakak" kepada saudara yang lebih tua dan "adik" kepada yang lebih muda, mendahulukan kepentingan orang lain. Berdoa sebelum melakukan aktifitas didalam rumah seperti : doa sebelum dan sesudah makan, doa sebelum dan sesudah masuk wc, doa sebelum dan sesudah tidur, doa ketika belajar, dan wajib diajarkan doa untuk ibu bapak (orangtua). Norma sosial yang perlu diajarkan kepada anak bisa kita mulai dengan aktivitas ringan didalam rumah, seperti : membantu orangtua mencuci piring, mencuci sepeda motor, menyapu rumah dan halaman rumah, mengisikan air dalam sumur dll.

Pendidikan dalam keluarga dilakukan tahap demi tahap sehingga tercapailah tujuan dalam pembentujan keluarga berpondasikan Alquran dan Hadis sebagai rujukan utama, yaitu :

a. Mendirikan syariat Allah dalam segala permasalahan rumah tangga 
b. Mewujudkan ketenteraman dan ketenangan psikologis.

c. Mewujudkan sunnah Rasulullah Saw dalam lingkungan rumah dan sekitarnya.

d. Memenuhi cinta dan kasih kepada anak-anak.

\section{Pendidikan Akhlak dalam Keluarga}

\section{a. Pendidikan Anak Ketika dalam Kandungan}

Ketika anak berusia 4 bulan dalam kandugan ibunya, maka dari sanalah roh mulai ditiupkan. Pendidikan dalam kandunganpun bisa kita mulai dari sini dengan ikhtiar beberapa metode yang sudah dipaparkan sebelumnya seperti metode kasih sayang, metode beribadah, metode membaca Alquran, metode pengajian di majelis ta'lim, metode penghargaan dengan ucapan, metode pemberian hadiah, metode bercerita, metode diskusi, metode tadzkirah, metode mengikut sertakan dengan ucapan, metode do'a, dan metode lagu. Karena apapun yang dilakukan dan dirasakan seorang ibu, begitu pula yang dirasakan oleh anak dalam kandungan. Sehingga perlu dipahami oleh orangtua keduanya, yakni suami dan isteri lebih menjaga sikap, perkataan, ataupun perbuatan disaat anak berada dalam kandungan. Sikap, perkataan dan perbuatan kedua orangtua akan sangat berpengaruh dengan kondisi anak nantinya.

Saling bekerja-sama diantara kedunya untuk membentuk akhlak yang baik bagi anak, diawali dengan musyawarah antar kedua orangtua untuk melakukan aktifitas-aktifitas positif ketika anak dalam kandungan. Aktifitas-aktifitas positif ini dapat dilakukan dengan memperdalam ibadah kepada Allah seperti aktifitas ibadah sehari-hari, seperti sholat dan baca Alquran, pengajian majelis ilmu dll . Semua aktifitas ini harus disertai diskusi dengan bayi yang ada dalam kandungan. Sebagai contoh ketika mau mengerjakan sholat maka ajar bayi dalam kandungan untuk sama-sama shalat, ketika ke majelis ilmu ajak bayi sama-sama mendengarkan tausyiah dari para ulama, atau ketika baca Alquran ajak juga bayi diskusi sambil 
mengelus-elus perut dengan kasih-sayang dan kelembutan untuk sama-sama mendengarkan bacaan Alquran dari ibunya.

Banyak kita temui para orangtua yang sholeh ketika mengandung, mereka memperdalam dan memperbanyak bacaan Alquran kepada sang bayi dengan niatan agar mereka nanti hafal Alquran 30 juz dimasa kanakkanak, dan hasilnya banyak yang menyelesaikan hafalan Alqurannya dimasa kanak-kanak. Sebagaimana sudah banyak anak-anak Indonesia saat ini yang ketika umuran 5 tahun, 7 tahun sampai 10 tahun sudah hafal 30 juz. Ini semua tidak lepas dari peran kedua orangtuanya yang menanamkan pendidikan Alquran ketika anak masih dalam kandungan ibunya.

Selain aktifitas yang positif, emosi sang ibu juga perlu dijaga dengan baik, tentunya ini juga ada kerjasama yang baik dari sang ayah untuk memahami keadaan si ibu yang sedang mengandung. Keadaan emosi yang baik akan membuat sang anak tumbuh dengan perilaku yang baik pula. Sebagai contoh : "ibu yang suka marah-marah ketika bayi masih dalam kandungan, akan berdampak buruk kepada anak ketika sudah keluar dari rahim ibunya. Bisa jadi itulah alasan kenapa anak susah diatur dan membuat jengkel kedua orangtuanya.

\section{b. Pendidikan Akhlak Pasca Melahirkan}

Hal pertama-tama yang harus dilakukan sang ayah ketika bayi sudah lahir adalah meng-azankan ditelinga anak. Tujuan dari azan adalah agar yang paling pertama didengar anak ketika berada dalam alam dunia adalah kalimat "Tauhid" yang mulia, kebesaran Allah menyelimuti semua organ tubuh, serta terhindar dari bisikan-bisikan syeitan pada anak.

Selanjutnya Tasmiah, tradisi tasmiah atau pemberian nama kepada anak ini sudah menjadi hal yang lumrah dimasyarakat. Tanpa kita sadari disinilah sebenarnya pendidikan akhlak kepada anak ditanamkam. Pemberian nama yang baik, mengambil nama-nama para nabi, ulama, orang-orang sholeh terdahulu dengan niatan agar anak berperilaku dengan perilaku yang baik pula nantinya dan bermanfaat bagi orang banyak. Dalam 
proses tasmiah, ada juga yang dinamakan tahnikah yang mana dalam kegiatannya memasukan korma atau makanan yang baik kedalam mulut anak, hal ini mengajari anak agar nantinya selalu memakan makanan yang halal lagi baik dan terhindar dari makanan-makanan yang diharamkan agama dan yang dapat membawa kepada kemudhoratan. Begitu juga dengan tahliah atau mencukur rambut bayi, ini mengajarkana anak agar selalu berperilaku bersih dan rapi dalam kehidupan sehari-hari.

Sangat pantas aqiqah diberi makna bersyukur dan bermurah hati. Mensyukuri akan kelahiran anak kemuka bumi dan bermurah hati menyembelih kambing untuk dibagikan kepada jiran tetangga. Hal ini akan didengar si anak ketika sudah besar dari tetangga sekitar hingga membekas di lubuk hatinya bahwa ketika dia kecil sudah diajarkan tuk berbagi kepada siapa saja.

Selain berakhlak kepada manusia, anak juga harus diajarkan bagaimana berakhlak kepada Allah sang pencipta seluruh alam. Berakhlak kepada Allah dapat diajarkan dengan cara mengikuti semua perintahperintah Allah. Diantaranya adalah melaksanakan perintah sholat lima waktu dalam sehari semalam, dan ajarkanlah perintah sholat ini ketika anak masih kecil. Ajak anak ke masjid untuk melaksanakan shalat berjama'ah agar tertanam didalam benaknya akan kecintaan kepada Masjid.

Akhlak kepada Rasulullah dan keluarga Rasulullah juga perlu diajarkan kepada anak selagi kecil. Agar anak tertanam rasa cinta kepada Rasulullah dan keluarga beliau, karena dijaman sekarang banyak ajaran yang mencaci-maki, bahkan memusuhi keluarga dan sahabat Rasulullah.

Tugas terakhir sebagai orangtua adalah mengawinkan anak bila sudah sampai waktunya. Namun sebelum dikawinkan, harus dibekali terlebih dahulu dengan ilmu dan pengetahuan tentang berkeluarga, apa hak dan kewajiban suami-isteri, mencari rizeki yang halal dalam berkeluarga, dan bagaimana mendidik anak nantinya apabila sudah mempunyai anak. 
Ahmad Rifa'i: Pendidikan Akhlak dalam Keluarga (Tinjauan Normatif dalam Islam)

\section{E. Simpulan}

Keluarga adalah sendi utama bagi jama'ah/masyarakat muslim dan keluarga sebagai micro sistem akan menentukan perkembangan jama' ah sebagai macro sistem. Oleh karena itu di dalam keluarga muslim proses Islamisasi seyogyanya berlangsung sejak lahir hingga meninggal. Dan Islam memandang penting fungsi keluarga dalam proses pendidikan anak.

Begitu juga pendidikan akhlak dalam keluarga seyogyanya ditanamkan sejak kecil kepada anak agar tertanam didalam dirinya untuk mencintai makhluk Allah, saling berbagi kebaikan dengan jiran tetangga maupun dengan orang lain. Selain berakhlak kepada makhluk Allah, juga perlu ditanamkan kepada anak agar berakhlak kepada Allah dan Rasulullah. Mencintai Allah melebihi cinta kepada makhluk, serta mencintai Rasulullah beserta keluarganya.

\section{F. Saran}

Penelitian ini diharapkan dapat membantu kemajuan pendidikan terutama pendidikan akhlak dalam keluarga. Dan tentunya penulisan ini jauh dari kata sempurna, pastinya banyak mempunyai kekurangan, karena itu diharapkan ada penelitian lanjutan guna mempelajari lebih dalam lagi tentang pendidikan akhlak dalam keluarga. 
Ahmad Rifa'i: Pendidikan Akhlak dalam Keluarga (Tinjauan Normatif dalam Islam)

\section{Daftar Pustaka}

Ali Quthb, Muhammad. Sang Anak dalam Naungan Pendidikan Islam (Auladuna fi Dau'I al Tarbiyah al Islamiah) Bahrun Abu Bakar Ihsan. Bandung : Diponegoro, 1988.

Atiyah al Abrasyi, Muhammad. Ruh at-Tarbiyah wa at-Ta'lim. Qahirah : Daru Ihya'I al-Kutubi al-Arabiah, 'Esa al-Baby al-Halaby wa Syirkah, 1955.

An-Nahlawi, Abdurrahman. Pendidikan Islam di Rumah, Sekolah, dan Masyarakat, Jakarta: Gema Insani Press, 2010 .

Asep, Usman Ismail. Al-Qur'an dan Kesejahteraan Sosial: Sebuah Rintisan Membangun Paradigma Sosial Islam Yang Berkeadilan dan Berkesejahteraan, Tangerang: Lentera Hati, 2012.

A.K. Baihaki. Mendidik Anak Dalam Kandungan Menurut Ajaran Pedagogis Islam, Jakarta : Darul Ulum Press, 2000.

Barnadib, Imam. Pemikiran Tentang Pemikiran Baru. Yogyakarta : Andi Offset, 1983.

Buseri, Kamrani. Pendidikan Keluarga dalam Islam. Yogyakarta : Bina Usaha Yogyakarta, 1990.

Daien Indrakusuma, Amir. Pengantar Ilmu Pemdidikan. Surabaya: Usaha Nasional, 1973.

Fuad, Ihsan. Dasar-dasar Kependidikan: Komponen MKDK. Jakarta: Rineka Cipta, 2010.

Hamdani, Ali H.B. Filsafat Pendidikan. Yogyakarta : Kota Kembang, 1987.

Hasbullah. Dasar-Dasar Ilmu Pendidikan. Jakarta : Raja Grafindo Prrsada, 2006.

Muhyi ad-Din, Abd Hamid Muhammad. Sunan Abi Daud. Juz 1 Beirut : Dar alFikr, tt.

Muhadjir, Noeng. Ilmu Pendidikan dan Perubahan Sosial Suatu Teori Pendidikan. Yogyakarta : Rake Sarasin, 1987.

Munir, A.Warson. Kamus Al-Munawir. Yogyakarta: Unit Pengadaan Bukubuku Ilmiah Keagamaan, 1984. 
Ahmad Rifa'i: Pendidikan Akhlak dalam Keluarga (Tinjauan Normatif dalam Islam)

Mahmud dkk., Pendidikan Agama Islam Dalam Keluarga: Sebuah Panduang Lengkap Bagi Guru, Orang Tua, dan Calon. Jakarta: Akademia, 2013.

Tafsir, Ahmad. Pendidikan Agama Dalam Keluarga. Bandung : PT. Remaja Rosdakarya. 2000.

Pusat Bahasa, Tim Penyusun Kamus. Kamus Besar Bahasa Indonesia. Jakarta: Balai Pustaka, 2005.

Ramayulis dkk, Pendidikan Islam Dalam Rumah Tangga. Jakarta: Kalam Mulia. 1990.

Setiawan, Agus. Konsep Pendidikan Tauhid dalam Keluarga Perspektif Pendidikan Islam, EDUCASIA, Vol. 2 No. 1, 2017.

Shochib, Moh., Pola Asuh Orang Tua: Dalam Membantu Mengembangkan Disiplin Diri Sebagai Pribadi Yang Berkarakter. Jakarta: Rineka Cipta: 2010.

Ulwani, Abdullah. Tarbiyah al-Auladi fi al-Islam. Juz 1 .Beirut : Dar as-Salam, 1981. 